\title{
obituary
}

\section{Dr Frances Felicity Kerr (née Gibbs)}

Felicity Kerr (her preferred name) was born on 3rd June 1923 into an affluent family in South Wales. It was traditional, within her social class and at that time, to send children to boarding school: in Felicity's case, to West Heath School in Kent. Unfortunately, this coincided with the perils of World War II and the onslaught of the Luftwaffe which, too frequently, chose to cross the coast dangerously near the school. In the interests of her safety, Felicity was moved back to Wales where, at Cardiff Technical College, she matriculated.

Having decided that medicine was to be her métier, she entered University College Hospital School, London, and qualified
MRCS, LRCP in 1949 and graduated MB, BS (London) in 1950. She completed her house jobs at Redhill Hospital, Surrey, and Whitchurch Hospital, Cardiff.

Her core job, however, was as a clinical assistant at the Manor Hospital, Epsom, known in those days as a hospital for 'mental defectives'. She found herself en rapport with her patients, particularly with children, and they with her - she was very content with her work which filled her professional life from 1972 until she retired in 1989. She had been an affiliate of the Royal College of Psychiatrists

In 1953, she married Donald Kerr, a barrister but a specialist in executor and trustee work. Duncan, their only child, was born in 1958.
Outside her work, Felicity was passionately fond of music, particularly opera, and, second in line, of the history of medicine: she was a regular and enthusiastic member of that section of the Royal Society of Medicine of which she was for a time Treasurer.

Sadly, her retirement was blighted by the increasing severity of her chronic diverticulitis that led to surgery and a permanent colostomy. A series of minor strokes culminating in a major stroke put paid to her life: she died on 3 January 2008.

She leaves behind her son (her husband predeceased her) and a host of friends and colleagues.

Henry R. Rollin

doi: 10.1192/pb.bp.108.020552 